УДК 665.7.032.57

\author{
ИЗУЧЕНИЕ ТЕРМОРАСТВОРЕНИЯ КЕРОГЕНА \\ В ТЯЖЕЛЫХ НЕФТЯНЫХ ОСТАТКАХ \\ С ЦЕЛЬЮ ИЗВЛЕЧЕНИЯ ОРГАНИЧЕСКОЙ ЧАСТИ
}

\title{
THE RESEARCH OF THERMAL DISSOLUTION OF KEROGEN IN HEAVY OIL RESIDUES FOR ORGANIC PART EXTRACTION
}

Юсупов М.Р., Камалов Р.М., Лапшин И.Г., Худайдатов Ю.В., Валинуров Р.P., Запорин В.П.

Уфимский государственный нефтяной технический университет, г. Уфа, Российская Федерация

M.R. Yusupov, R.M. Kamalov, I.G. Lapshin, Yu.V. Khudaidatov, R.R. Valinurov, V.P. Zaporin

Ufa State Petroleum Technological University, Ufa, Russian Federation e-mail: marsel.yusupov.2014@mail.ru,inftek@yandex.ru

Аннотация. В статье рассмотрена возможность терморастворения керогена в тяжелых нефтяных остатках. Сейчас во всем мире происходит постепенное истощение ресурсов легких и малосернистых нефтей, наблюдается все большее вовлечение в переработку тяжелых высоковязких нефтей, из-за чего трудность переработки возрастает. В будущем потребность в энергоносителях и рост темпа потребления нефти будут неминуемо возрастать, из-за чего сейчас по всему миру ведутся поиски альтернативных энергоносителей. Одной из будущих перспективных отраслей считается сланцепереработка.

Горючий сланец состоит из минеральной части и органической составляющей, которая интересна в качестве источника углеводородов. На 
данный момент наибольшее распространение в промышленности нашли процессы переработки в газогенераторах, в которых сланец, контактируя с горячим теплоносителем, выделяет сланцевую смолу, похожую на нефть. Запасов сланцевой смолы в мире в несколько раз больше оставшихся запасов традиционной нефти.

На сегодняшний момент методы переработки горючих сланцев требуют больших затрат на добычу, транспортировку, измельчение, нагрев, a также утилизацию полученных отходов, что повышает себестоимость сланцевой смолы по сравнению с нефтью. Все перечисленные недостатки сдерживают рост сланцеперерабатывающей промышленности.

Одним из перспективных способов по извлечению керогена, органической массы, является терморастворение. Представлены материальные балансы процессов коксования керогена, терморастворения керогена в двух растворителях. Дана сравнительная оценка физикохимических свойств тяжелых нефтяных остатков. Выведены температурные кривые и динамика выделения газа при проведении процессов. Определены групповые углеводородные составы остатков при различном времени проведения. Оценена возможность терморастворения керогена в нефтяных остатках.

Abstract. The article deals with the possibility of thermal dissolution of kerogen in heavy oil residues. Now all over the world there is a gradual depletion of the resources of light and low-sulfur oils, there is growing involvement in the processing of heavy highly viscosity oils, which increases the complexity of processing. In the future, the need for energy carriers and the growth in the rate of oil consumption will inevitably increase, that is why the search for alternative energy sources is being carried out around the world. One of the future promising sectors is shale processing.

Shale consists of a mineral part and an organic component that is interesting as a source of hydrocarbons. At the moment the spread of industrial introduction 
has foundrefinery processingin gasification reactor, where the shale contacting with the hot heat carrier and produces crude shale oil which similar to oil. In the world of reserves of shale oil, several times more than the remaining reserves of traditional oil.

At present time, methods of processing of shales require large costs for extraction, transportation, grinding, heating, and also utilization of the waste, which overstates the cost price of crude shale oil in comparison with oil. All these shortcomings hamper the growth of the shale processing industry. One of the promising methods for extracting kerogen is thermal dissolution.

Material balances of the processes of coking kerogen, thermal dissolution of kerogen in two solvents are presented. A comparative assessment of the physical and chemical properties of heavy oil residues is given. The temperature curves and the dynamics of evolution of gas during the process are derived. The group hydrocarbon compositions of the residues are determined at different times. The possibility of thermal dissolution of kerogen in oil residues is estimated.

Ключевые слова: переработка, терморастворение, кероген, сланцы, мазут, нефтяные остатки, сланцевая смола.

Key words: recycling, thermal dissolution, kerogen, shale, fuel oil, residual oil, shale oil.

Поиски альтернативных источников энергоносителей углеводородного происхождения показали, что заменой традиционной нефти могут быть горючие сланцы $[1,2]$. Они состоят из органической части (от $5 \%$ до $50 \%$ ) и минеральной части, представленной различными горными породами и металлами. Подвергая горючие сланцы воздействию высоких температур, получаем разложение органического вещества и выделение образовавшейся углеводородной смеси. Причем полученная органическая масса по составу очень похожа на традиционную нефть, отличаясь некоторыми специфическими особенностями $[3,4]$. 
Заключенное и вкрапленное в виде сферических образований в сланцевых породах органическое вещество - кероген - является скоплением макромолекул в виде конденсированных карбоциклических ядер, связанных в виде алифатических цепочек или гетероатомных связей. Он может быть разных типов в зависимости от условий залеганий, геохимических и биохимических превращений $[5,6]$. Стоит отметить также, что кероген при комнатной температуре не растворяется в органических растворителях, что говорит о сложной пространственной структуре его макромолекул.

Технологии по получению органической смеси из сланцевых пород различаются по принципу выделения. На сегодняшний день существует множество различных способов производства нефти из сланцев. Существует методы наземного пиролиза, когда добытые куски сланца дробят, и загружают полученную мелкозернистую фракцию в газогенераторы, где происходит нагрев и выделение парогазовой смеси, а также подземного пиролиза, когда нагрев осуществляют различными способами прямо на сланценосных скважинах без добычи и дробления [7]. Способы пиролиза отличаются как выходом, так и качеством получаемой сланцевой смолы, однако такие технологии требуют больших энергозатрат, что увеличивает себестоимость такого производства по сравнению с нефтью. Активно ведутся исследования по разработке технологий извлечения органической массы, минуя все трудоемкие процедуры по добыче, транспортировке, дроблению, рассеиванию и отделению минеральной части сланцевых пород.

Одним из перспективных способов извлечения углеводородной составляющей является терморастворение органической части сланца в соответствующем растворителе, который при определенной температуре деполимеризует полимерную структуру керогена, вшитую в минеральную матрицу сланца, и растворяет ее в себе [8]. 
Для изучения возможности выделения органического вещества из горючих сланцев был взят кероген-90 - сланцевый концентрат, полученный при флотации прибалтийского сланца. Был проанализирован его элементный состав $(\mathrm{C}-58,8$ \% масс., $\mathrm{H}-7,1$ \% масс., $\mathrm{S}-0,97$ \% масс., зольность $-9,9 \%$ масс.), провели его коксование при температуре $470{ }^{\circ} \mathrm{C}$ в течении 2,5 ч для получения материального баланса без применения растворителей.

Коксование керогена, а также его терморастворение проводили в реакторе ампульного типа, изображенного на рисунке 1. Загрузка пробы в ампульный реактор составляет около 20 г.

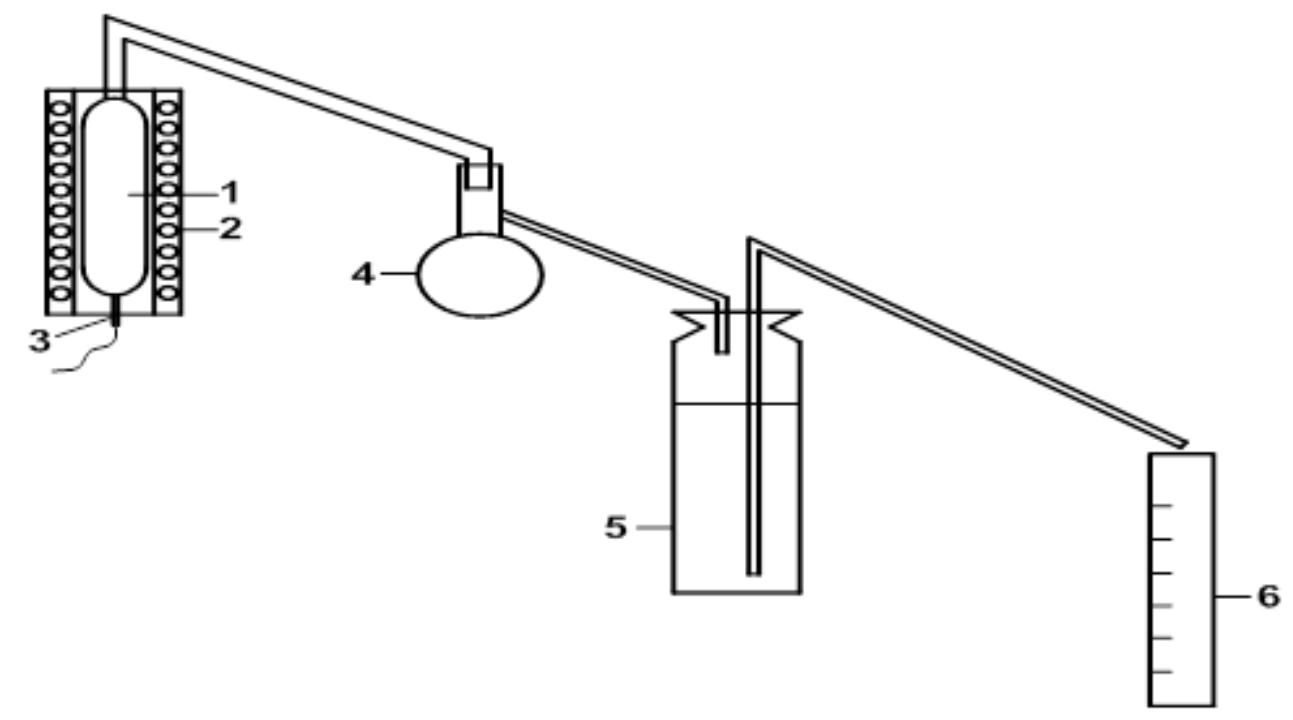

1 - стеклянный реактор; 2 - нагревательная печь;

3 - термопара, соединенная с регулятором;

4 - приемник дистиллята; 5 - склянка Дрекселя;

6 - мерный цилиндр для измерения объема выделившегося газа

Рисунок 1. Принципиальная схема лабораторной установки

При коксовании керогена получили следующие продукты с различным выходом: газ - $13 \%$, дистиллят - $40 \%$, остаток - $47 \%$. Визуально в дистилляте на дне приемной колбы содержится большое количество пирогенетической воды. Провели имитированную разгонку обезвоженного дистиллята на газовом хроматографе, в результате чего выявили, что 
17,6\% дистиллята - бензиновая фракция (фр. 50-180 $\left.{ }^{\circ} \mathrm{C}\right), 15,2 \%$ - легкий газойль (фр. $\left.180-350{ }^{\circ} \mathrm{C}\right), 7,2 \%$ - тяжелый газойль $\left(ф р .>350{ }^{\circ} \mathrm{C}\right)$. Остаток коксования подобен коксу, рыхлый, пористый, с низкой механической прочностью.

Был проведен ряд опытов по терморастворению керогена-90 с применением двух потенциально разных растворителей: одним является тяжелый газойль каталитического крекинга (ТГКК) с установки Г-43-107/M1, а в качестве другого был взят товарный мазут. Характеристика этих растворителей представлена в таблице 1.

Предположительно, тяжелый каталитический газойль термостабилен и способен при крекинге выделять атомарный водород, который будет подвергать полимерную структуру керогена деструкции. Товарный мазут, напротив, содержит большое количество нестабильных при нагревании парафиновых структур.

Условия экспериментов были следующие: соотношение нефтяного остатка к керогену-90 - 70 : 30 по массе.

Смесь нагревалась с определенной скоростью до $400{ }^{\circ} \mathrm{C}$ и выдерживалась при заданной температуре в течение от 1 до 3 ч.

Давление выдерживалось атмосферное. Далее остаток извлекался из реактора, и в остатке определялось содержание нерастворимых в толуоле веществ.

Материальный баланс терморастворения в двух различных растворителях и качество полученных продуктов в этом процессе, приведенных в таблице 2. 
Таблица 1. Свойства нефтяных остатков как основы для терморастворения керогена-90

\begin{tabular}{|c|c|c|}
\hline Наименование показателей & $\begin{array}{l}\text { Топочный } \\
\text { мазут }\end{array}$ & $\begin{array}{c}\text { Тяжелый газойль } \\
\text { каталитического } \\
\text { крекинга }\end{array}$ \\
\hline Плотность при $20^{\circ} \mathrm{C}, \Gamma / \mathrm{cm}^{3}$ & 0,9273 & 1,0396 \\
\hline Коксуемость, \% масс. & 2,52 & 2,93 \\
\hline Содержание серы, \% масс. & 1,12 & 1,14 \\
\hline \multicolumn{3}{|c|}{ Вязкость кинематическая, сСт } \\
\hline при $50{ }^{\circ} \mathrm{C}$ & 56,75 & 43,89 \\
\hline при $80^{\circ} \mathrm{C}$ & 17,27 & 11,74 \\
\hline \multicolumn{3}{|l|}{ Фракционный состав } \\
\hline температура н.к., ${ }^{\circ} \mathrm{C}$ & 230 & 219 \\
\hline 5 \% об. выкипает при $\mathrm{t},{ }^{\circ} \mathrm{C}$ & 366 & 308 \\
\hline 10 \% об. выкипает при t, ${ }^{\circ} \mathrm{C}$ & 354 & 336 \\
\hline 30 \% об. выкипает при $\mathrm{t},{ }^{\circ} \mathrm{C}$ & 390,5 & 378 \\
\hline 50 \% об. выкипает при t, ${ }^{\circ} \mathrm{C}$ & 421,5 & 400 \\
\hline 90 \% об. выкипает при t, ${ }^{\circ} \mathrm{C}$ & 500 & 475 \\
\hline \multicolumn{3}{|c|}{ Групповой углеводородный состав, \% масс. } \\
\hline $\begin{array}{l}\text { парафино-нафтеновые } \\
\text { углеводороды }\end{array}$ & - & 16,9 \\
\hline ароматические углеводороды & - & 74,5 \\
\hline $\begin{array}{l}\text { легкие ароматические } \\
\text { углеводороды }\end{array}$ & - & 4,3 \\
\hline $\begin{array}{l}\text { средние ароматические } \\
\text { углеводороды }\end{array}$ & - & 8,2 \\
\hline $\begin{array}{l}\text { тяжелые ароматические } \\
\text { углеводороды }\end{array}$ & - & 62,0 \\
\hline смолы & - & 7,2 \\
\hline I типа смолы & - & 2,2 \\
\hline II типа смолы & - & 5,0 \\
\hline асфальтены & - & 1,4 \\
\hline
\end{tabular}


Таблица 2. Материальный баланс терморастворения керогена-90 в ТГКК и мазуте

\begin{tabular}{|c|c|c|c|c|c|c|}
\hline Растворитель & \multicolumn{3}{|c|}{ ТГКК } & \multicolumn{3}{|c|}{ Мазут } \\
\hline $\begin{array}{l}\text { Время выдержки } \\
\text { при } 400^{\circ} \mathrm{C}, \text { ч }\end{array}$ & 1 & 2 & 3 & 1 & 2 & 3 \\
\hline Газ + потери, \% & 2,4 & 2,7 & 3,8 & 2,5 & 3,3 & 5,1 \\
\hline Дистиллят, \% & 5,0 & 7,2 & 14,2 & 12,5 & 16,4 & 27,2 \\
\hline Остаток, \% & 92,6 & 90,1 & 82,0 & 85,0 & 80,3 & 67,7 \\
\hline $\begin{array}{l}\text { Объем отобранного } \\
\text { газа, мл }\end{array}$ & 306 & 418 & 688 & 351 & 467 & 664 \\
\hline \multicolumn{7}{|c|}{ Групповой углеводородный состав остатков } \\
\hline $\begin{array}{l}\text { - Парафино- } \\
\text { нафтеновые } \\
\text { углеводороды }\end{array}$ & 7,5 & 5,3 & 8,0 & 35,7 & 40,9 & 38,4 \\
\hline $\begin{array}{l}\text { - Ароматические } \\
\text { углеводороды: }\end{array}$ & 65,3 & 64,2 & 56,0 & 32,0 & 28,9 & 39,1 \\
\hline легкие & 0,7 & 1,5 & - & 8,8 & 4,2 & 13,2 \\
\hline средние & 1,6 & 0,6 & - & 7,4 & 9,9 & 6,9 \\
\hline тяжелые & 63 & 62,1 & 56,0 & 15,8 & 14,8 & 19,0 \\
\hline - Смолы: & 14,7 & 21,9 & 25,2 & 26,4 & 25,0 & 17,7 \\
\hline I & 6,4 & 7,0 & 6,3 & 7,6 & 6,5 & 5,8 \\
\hline II & 8,3 & 14,9 & 18,9 & 18,8 & 18,5 & 11,9 \\
\hline - асфальтены & 12,5 & 8,6 & 10,8 & 5,9 & 7,0 & 4,8 \\
\hline Итого & 100,0 & 100,0 & 100,0 & 100,0 & 100,0 & 100,0 \\
\hline $\begin{array}{l}\text { Определение } \\
\text { содержания в } \\
\text { смесях } \\
\text { нерастворимых в } \\
\text { толуоле (ТЈ) в } \\
\text { соотношении } \\
\text { керогена-90 к } \\
\text { нефтяному остатку } \\
30: 70, \% \text { по масс. } \\
\end{array}$ & 7,68 & 4,53 & 8,03 & 4,24 & 4,60 & 7,12 \\
\hline
\end{tabular}

Из таблицы 2 видно, что после увеличения времени термообработки смеси керогена с тяжелым каталитическим газойлем ароматические углеводороды превращаются в смолы. В смеси мазута и керогена наблюдается обратная картина, когда смол и асфальтенов становится меньше, а парафино-нафтеновых и ароматических углеводородов больше. 
Данное наблюдение свидетельствует, что мазут более предпочтителен для деполимеризации структуры керогена.

До термообработки смеси керогена с растворителями содержание не растворимых в толуоле составляющих почти $30 \%$, т.е. если кероген-90 нерастворим, то после термообработки содержание не растворимых составляющих в толуоле изменяется от $4 \%$ до $8 \%$. Таким образом, мазут оказался более предпочтителен для терморастворения керогена-90, чем ТГКК.

Были проведены 2 эксперимента на пилотной установке по коксованию.

В первом опыте использовалась смесь керогена с мазутом в соотношении 30 : 70, а во втором опыте в качестве сырья загружался только мазут. Загрузка в коксовый реактор во всех опытах составляла 850 г.

При проведении опытов был отобран газ для хроматографического анализа. Давление в экспериментах поддерживалось 3,5 кг/см².

На рисунках 2 и 3 приведены кривые изменения температуры в ходе процесса и динамика выделения газа.

Различия по выходу в продуктах при коксовании смеси керогена с растворителем и мазута заключается в большем выходе газа при коксовании с керогеном (5,5 \% против $1,1 \%)$, наличии пирогенетической воды в дистилляте терморастворения смеси керогена с мазутом (около $1,4 \%)$. Количество фракций выкипающих выше $350{ }^{\circ} \mathrm{C}(69,5 \%$ против $76,2 \%)$. Выходы бензиновых (4,8 \% против 4,2 \%) и газойлевых $(18,8 \%$ против 18,5 \%) фракций почти одинаковы.

Для сравнения остатков термообработки мазута и смеси мазута с керогеном были проведены разгонки полученных остатков и определены плотности узких фракций. Полученные данные представлены в таблице 3. 


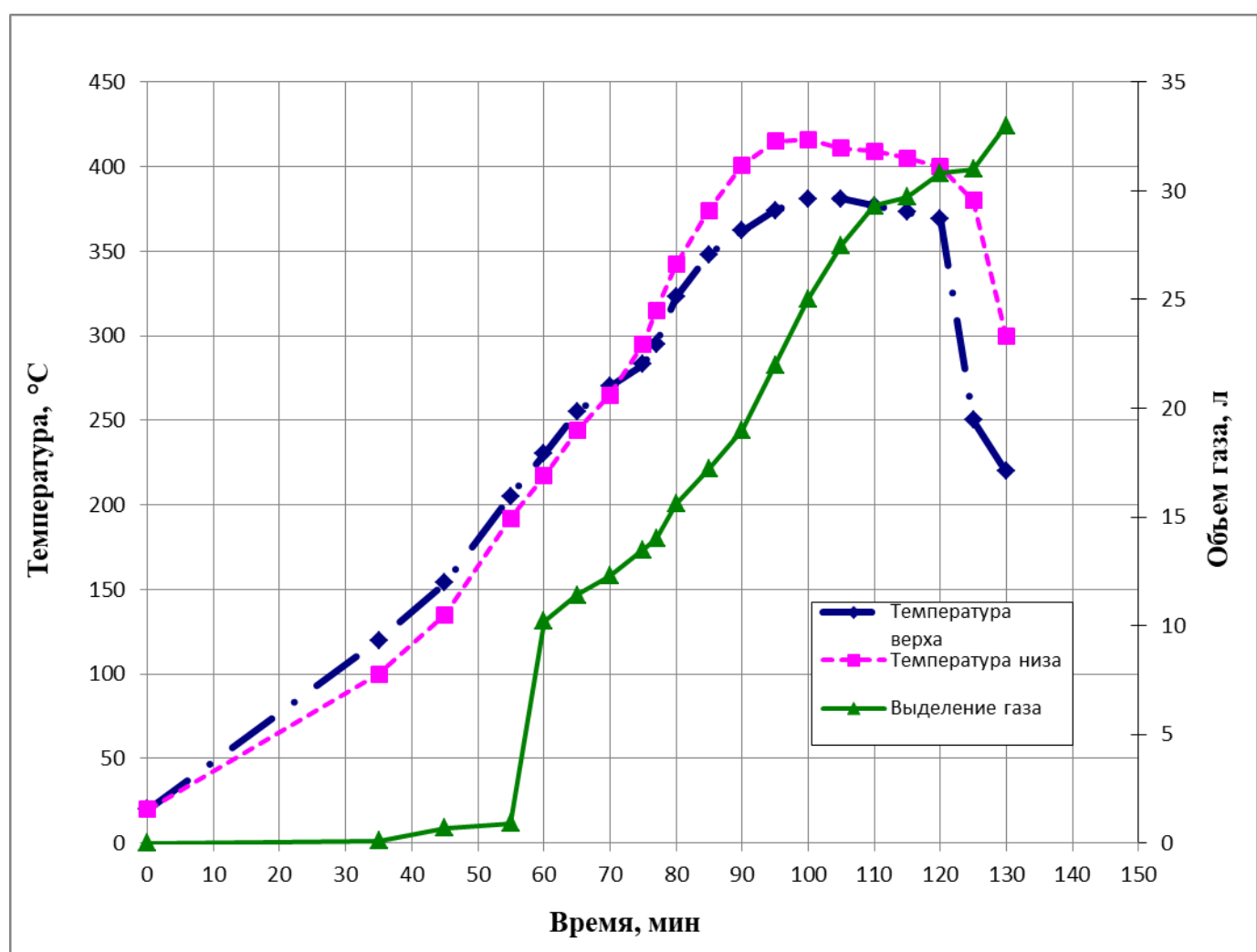

Рисунок 2. Температурные условия проведения термообработки смеси мазута с керогеном-90 (70:30) и динамика выделения газа (опыт 1)

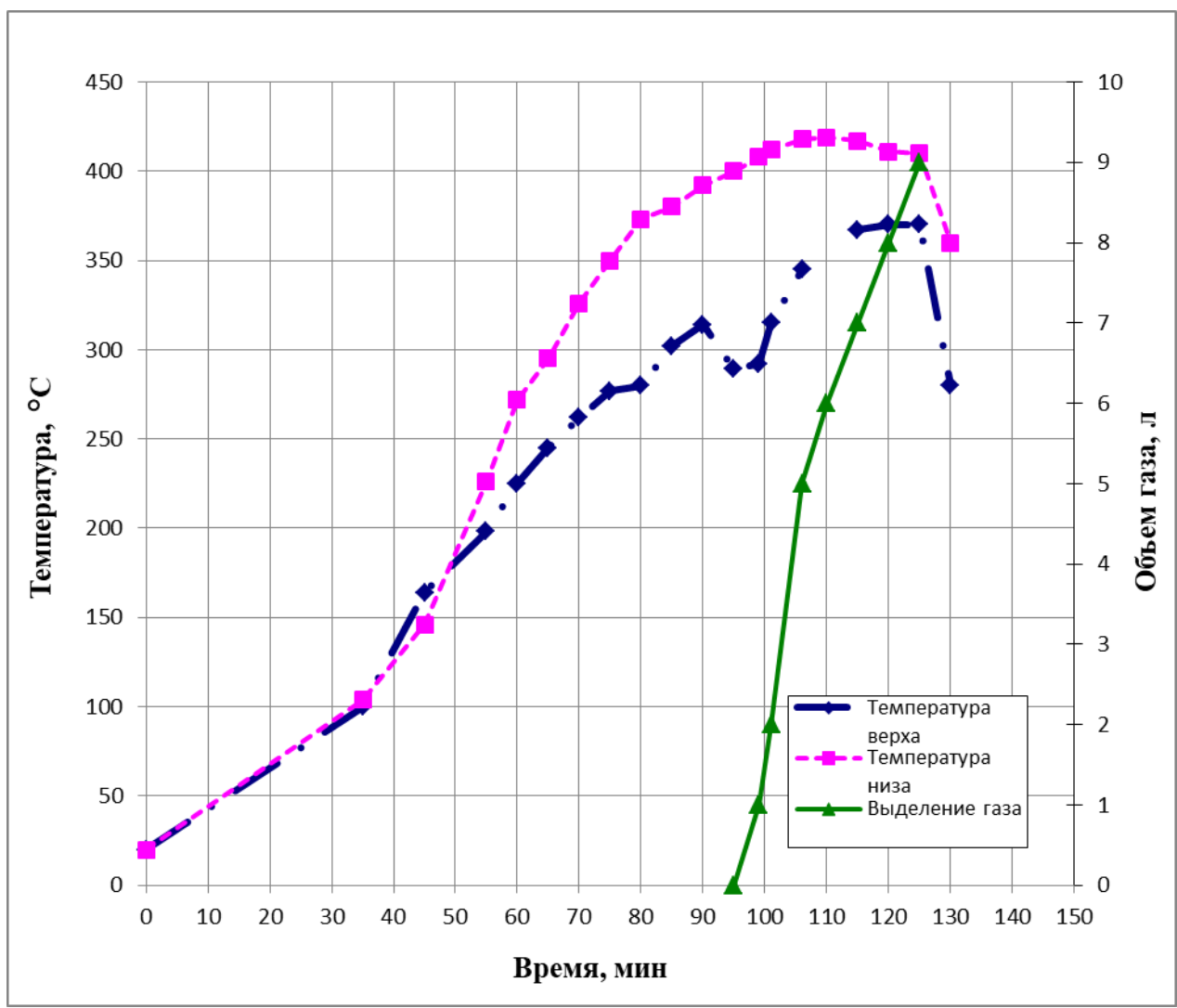

Рисунок 3. Температурные условия и динамика выделения газа при термообработке мазута (опыт 2) 
Таблица 3. Разгонка по ИТК остатков термообработки сырья

\begin{tabular}{|c|c|c|c|c|}
\hline \multirow{3}{*}{$\begin{array}{l}\text { Фракция, } \\
{ }^{\circ} \mathrm{C}\end{array}$} & \multicolumn{4}{|c|}{ Сырье термообработки } \\
\hline & \multicolumn{2}{|c|}{$\begin{array}{c}\text { Смесь мазута с } \\
\text { керогеном-90 (70:30) }\end{array}$} & \multicolumn{2}{|r|}{ Мазут } \\
\hline & $\begin{array}{l}\text { Выхо } \\
\text { д, \% }\end{array}$ & $\begin{array}{c}\text { Плотность, } \\
\Gamma^{\Gamma / \mathrm{cm}^{3}} \\
\end{array}$ & Выход, \% & 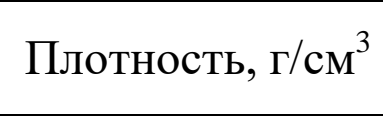 \\
\hline н.к.-300 & 6,42 & 0,8787 & 5,6 & 0,8588 \\
\hline $300-350$ & 11,31 & 0,9094 & 10,37 & 0,8931 \\
\hline $350-380$ & 11,09 & 0,9182 & 13,68 & 0,9081 \\
\hline $380-410$ & 14,13 & 0,9290 & 18,37 & 0,9176 \\
\hline $410-440$ & 10,93 & 0,9431 & 15,67 & 0,9304 \\
\hline $440-470$ & 10,43 & 0,9570 & 13,07 & 0,9422 \\
\hline $470-500$ & 7,46 & 0,9752 & 7,39 & 0,9546 \\
\hline$>500$ & 28,23 & 1,1473 & 15,85 & 1,0188 \\
\hline Итого & 100,0 & & 100,0 & \\
\hline
\end{tabular}

Углеводородный газ термообработки смеси мазута с керогеном-90 состоит преимущественно из $\mathrm{CO}(8,56 \%)$ и $\mathrm{CO}_{2}(54,94 \%)$, что, учитывая образование пирогенетической воды, свидетельствует о высоком содержании кислорода в керогене-90. Причем, если при термообработке исходного мазута газообразование начинается при достижении температуры в реакторе $400{ }^{\circ} \mathrm{C}$, когда собственно и начинаются обычные процессы термического крекинга нефтяного сырья, то при термообработке смеси мазута с керогеном-90 интенсивное газообразование начинается при достижении температуры в реакторе всего $250{ }^{\circ} \mathrm{C}$. Это свидетельствует о том, что не углеводороды мазута являются инициатором деструкции керогена-90, а сама полимерная структура керогена-90 в силу наличия слабых связей начинает подвергаться термическим превращениям при столь низких температурах термообработки, т.е. используемый нефтяной остаток (в нашем случае мазут) является лишь средой, где протекают термические превращения керогена-90. Причем, как это видно из представленных данных по материальному балансу, а также данных о плотностях узких фракций остатков (таблица 3), термолиз керогена-90 протекает преимущественно с образованием тяжелокипящих фракций, 
выкипающих выше $300-350{ }^{\circ} \mathrm{C}$. В таблице 4 представлены характеристики полученных фракций, выкипающих выше $300{ }^{\circ} \mathrm{C}$.

Таблица 4. Характеристика фракций, выкипающих выше $300{ }^{\circ} \mathrm{C}$ после термообработки

\begin{tabular}{|c|c|c|}
\hline \multirow[b]{2}{*}{ Показатели качества } & \multicolumn{2}{|c|}{$\begin{array}{c}\text { Сырье термообработки, } \\
\text { номер опыта }\end{array}$} \\
\hline & $\begin{array}{c}\text { Смесь мазута } \\
\text { с керогеном-90 } \\
(70: 30), \\
\text { опыт } 1 \\
\end{array}$ & $\begin{array}{l}\text { Мазут, } \\
\text { опыт } 2\end{array}$ \\
\hline 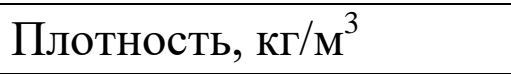 & 0,9947 & 0,9387 \\
\hline $\begin{array}{l}\text { Содержание серы, } \\
\text { \% масс. }\end{array}$ & 0,80 & 1,02 \\
\hline $\begin{array}{l}\text { Вязкость условная, } \\
\text { при } 80^{\circ} \mathrm{C},{ }^{\circ} \mathrm{E}\end{array}$ & 9,6 & 2,2 \\
\hline $\begin{array}{l}\text { Содержание } \\
\text { нерастворимых в } \\
\text { толуоле, \% }\end{array}$ & 3,7 & - \\
\hline $\begin{array}{l}\text { Содержание фракций, } \\
\text { выкипающих } \\
\text { выше } 500^{\circ} \mathrm{C}, \% \text { масс. }\end{array}$ & 26,4 & 15,0 \\
\hline
\end{tabular}

Интересно сравнить полученные остатки термообработки мазута и смеси мазута с керогеном. Исходный товарный мазут имел большой запас по вязкости. После его легкой термообработки с образованием около $20 \%$ легкокипящих (до $300{ }^{\circ} \mathrm{C}$ ) фракций, качество его практически не изменилось, за исключением некоторого повышения плотности. При термообработке смесей мазута с керогеном-90 качественные показатели остатков выше $300{ }^{\circ} \mathrm{C}$ существенно изменились: увеличилась плотность и в 4 раза увеличилась вязкость, что обусловлено влиянием присутствия в этих фракциях высококипящих продуктов, образовавшихся при термических превращениях собственно самого керогена-90. Примечательны значения плотностей фракций, выкипающих выше $500{ }^{\circ} \mathrm{C}$, входящих в состав этих остатков. 
Представленные в таблице 4 данные и то, что термообработка смесевого сырья в опыте 1 осуществлялась при несколько меньшей температуре, еще раз подтверждают предположение о том, что термообработку керогена-90 необходимо осуществлять с минимально возможным разложением, при котором протекают реакции термолиза по наиболее слабым связям с расшивкой полимерной структуры.

\section{Выводы}

Хотя кероген и нерастворим в большинстве растворителей при комнатной температуре, как показали эксперименты, проведенные на пилотной установке, при термообработке смеси нефтяных остатков с керогеном-90, действительно, наблюдается терморастворение керогена-90, т.е. его полимерная структура действительно «растаскивается» на отдельные составляющие, причем при чрезвычайно низких температурах. Однако растворитель не является инициатором расшивки полимерной структуры керогена, а лишь является средой благоприятствующей деполимеризации керогена.

Данные наблюдения показывают, что нефтяные остатки можно использовать для извлечения органического вещества, заключенного в сланцевых породах при оптимальной температуре.

\section{Список используемых источников}

1. Морариу Д., Аверьянова О.Ю. Некоторые аспекты нефтеносности сланцев: понятийная база, возможности оценки и поиск технологий извлечения нефти // Нефтегазовая геология. Теория и практика. 2013. Т. 8. № 1. C. 21.

2. Мамахатов Т.М. Прогноз развития нетрадиционных источников углеводородов в мировой энергетике // Интерэкспо Гео-Сибирь. 2012. Т. 1. № 3. С. 149-154. 
3. Назаренко М.Ю., Бажин В.Ю., Салтыкова С.Н., Коновалов Г.В. Изучение физико-химических свойств горючих сланцев // Кокс и химия. 2014. № 3. С. 44-49.

4. Зеленин Н.К., Файнберг В.С., Чернышева К.В. Химия и технология сланцевой смолы. Л.: Химия. 1968. 308 с.

5. Бушнев Д.А., Бурдельная Н.С. Химическая структура керогена и условия его формирования // Геология и геофизика. 2009. Т. 50, № 7. C. 822-829.

6. 6. Бушнев Д.А., Бурдельная Н.С. Химическая структура керогена // Вестник института геологии Коми научного центра Уральского отделения PAH. 2010. № 9. C. 36-37.

7. Рудин М.Г., Серебрянников Н.Д. Справочник сланцепереработчика. Л.: Химия, 1988. 256 с.

8. Фугалья А., Потехин В.М., Сыроежко А.М. Терморастворение рядовых и обогащенных сланцев в остаточных продуктах переработки нефти и сланцехимических смолах // Известия Санкт-Петербургского государственного технологического института (технического университета). 2007. № 2. С. 70-74.

\section{References}

1. Morariu D., Aver'yanova O.Yu. Nekotorye aspekty neftenosnosti slantsev: ponyatiinaya baza, vozmozhnosti otsenki i poisk tekhnologii izvlecheniya nefti [Some of Aspects of Oil Content of Shales: Definitions, Possibilities Evaluation and Search Technology Extraction Oil]. Neftegazovaya geologiya. Teoriya i praktika - - Oil and Gas Geology. Theory and Practice, 2013, Vol. 8, No. 1, pp. 21. [in Russian].

2. Mamakhatov T.M. Prognoz razvitiya netraditsionnykh istochnikov uglevodorodov $\mathrm{v}$ mirovoi energetike [Estimate of Development of Unconventional Sources of Hydrocarbons in Worlds Practice]. Interekspo GeoSibir' - InterExpo Geo-Siberia, 2012, Vol. 1, No. 3, pp. 149-154. [in Russian]. 
3. Nazarenko M.Yu., Bazhin V.Yu., Saltykova S.N., Konovalov G.V. Izuchenie fiziko-khimicheskikh svoistv goryuchikh slantsev [Study of the Physicochemical Properties of Oil Shales]. Koks i khimiya - Coke and Chemistry, 2014, No. 3, pp. 44-49 [in Russian].

4. Zelenin N.K., Fainberg V.S., Chernysheva K.V. Khimiya i tekhnologiya slantsevoi smoly [Chemistry and Technology of Shale Oil]. Leningrad, Chemistry Publ., 1968. 308 p. [in Russian].

5. Bushnev D.A., Burdel'naya N.S. Khimicheskaya struktura kerogena i usloviya ego formirovaniya [Chemical Structure of Kerogen and Conditions of Its Formation]. Geologiya i geofizika - Geology and Geophysics, 2009, Vol. 50, No. 7, pp. 822-829. [in Russian].

6. Bushnev D.A., Burdel'naya N.S. Khimicheskaya struktura kerogena [Chemical Structure of Kerogen]. Vestnik instituta geologii Komi nauchnogo tsentra Ural'skogo otdeleniya RAN - Herald of Komi Geology University of Scientific Center of RAS Ural's Department, 2010, No. 9, pp. 36-37. [in Russian].

7. Rudin M.G., Serebryannikov N.D. Spravochnik slantsepererabotchika. [Shale-Processor Handbook]. Leningrad, Chemistry Publ., 1988. 256 p. [in Russian].

8. Fugal'ya A., Potekhin V.M., Syroezhko A.M. Termorastvorenie ryadovykh i obogashchennykh slantsev $\mathrm{v}$ ostatochnykh produktakh pererabotki nefti i slantsekhimicheskikh smolakh [Termodissolution Ordinary and Concentrate Shale in Shale Chemical Oil and Residual Products of Refining Oil]. Izvestiya Sankt-Peterburgskogo gosudarstvennogo tekhnologicheskogo instituta (tekhnicheskogo universiteta) - News of Saint-Petersburg's State Technologic Institute (Technical University), 2007, No 2, pp. 70-74. [in Russian]. 


\section{Сведения об авторах}

\section{About the authors}

Юсупов М.Р., магистрант кафедры «Технология нефти и газа», ФГБОУ ВО «УГНТУ», г. Уфа, Российская Федерация

M.R. Yusupov, Undergraduate Student of Oil and Gas Technology Department, FSBEI HE «USPTU», Ufa, Russian Federation

e-mail: marsel.yusupov.2014@mail.ru

Камалов Р.М., магистрант кафедры «Технология нефти и газа», ФГБОУ ВО «УГНТУ», г. Уфа, Российская Федерация

R.M. Kamalov, Undergraduate Student of Oil and Gas Technology Department, FSBEI HE «USPTU», Ufa, Russian Federation

Лапшин И.Г., аспирант кафедры «Технология нефти и газа», ФГБОУ ВО «УГНТУ», г. Уфа, Российская Федерация

I.G. Lapshin, Post-graduate Student of Oil and Gas Technology Department, FSBEI HE «USPTU», Ufa, Russian Federation

Худайдатов Ю.В., магистрант кафедры «Технология нефти и газа», ФГБОУ ВО «УГНТУ», г. Уфа, Российская Федерация

Yu.V. Khudaidatov, Undergraduate Student of Oil and Gas Technology Department, FSBEI HE «USPTU», Ufa, Russian Federation

Валинуров Р.Р., аспирант кафедры «Технология нефти и газа», ФГБОУ ВО «УГНТУ», г. Уфа, Российская Федерация

R.R. Valinurov, Post-graduate Student of Oil and Gas Technology Department, FSBEI HE «USPTU», Ufa, Russian Federation

Запорин В.П., канд. техн. наук, доцент кафедры «Технология нефти и газа», ФГБОУ ВО «УГНТУ», г. Уфа, Российская Федерация

V.P. Zaporin, Candidate of Engineering Sciences, Assistant Professor of Oil and Gas Technology Department, FSBEI HE «USPTU», Ufa, Russian Federation 